\title{
REKLAMA W DZIAŁANIACH KOMUNIKACYJNYCH JEDNOSTKI SAMORZĄDU TERYTORIALNEGO
}

\author{
ADVERTISING IN A SELF-GOVERNMENT UNIT'S \\ COMMUNICATION ACTIVITIES
}

Dariusz Krawczyk*

\begin{abstract}
Abstrakt
Artykuł dotyczy aktywności samorządów w obszarze komunikacji perswazyjnej. Celem jest określenie zasadności i zgodności z przepisami podejmowanych działań oraz wskazanie na uwarunkowania, którym odpowiadać powinna polityka reklamowa administracji publicznej. Przedstawiono charakterystykę przedsięwzięć promocyjnych realizowanych zarówno bezpośrednio przez gminy lub powiaty, jak i za pośrednictwem nadawców zewnętrznych, a w tym środków masowego przekazu. Zaprezentowano ponadto wyniki badań empirycznych dotyczących technik i narzędzi reklamy jednostek samorządu terytorialnego, ich społecznego zasięgu oraz wysokości nakładów budżetowych przeznaczanych na promocję.
\end{abstract}

Słowa kluczowe: samorząd, promocja, reklama natywna, reklama porównawcza, media samorządowe

\begin{abstract}
The article concerns the activity of local self-governments in the area of persuasive communication. What it aims at is determining the legitimacy and compliance of the actions taken with the applicable regulations and also at indicating the conditions that should be met by public administration advertising policy. The characteristics of promotional schemes implemented directly by municipalities and communes as well as through external broadcasters, including mass media, was presented. Furthermore, the article presents and discusses the results of empirical research on advertising techniques and tools available to local selfgovernment units, their social outreach and the amount of budgetary expenditure allocated for promotion.
\end{abstract}

Key words: local self-government, promotion, native advertising, comparative advertising, local self-government media

p1): (iD hipttps://orcid.org/0000-0003-1823-0309. 


\section{Wprowadzenie}

Samorządy, realizując zadania własne, podejmują próby zwrócenia uwagi odbiorców na przygotowane w ramach działań gminy lub powiatu produkty, składające się na ofertę edukacyjną, turystyczną, rekreacyjną, inwestycyjną itp. Wdrażając założenia marketingu terytorialnego, korzystają $\mathrm{z}$ wielu technik i sposobów dotarcia z przekazem do grup docelowych. W zależności od przyjętej strategii oraz z uwzględnieniem potencjału danej jednostki samorządu terytorialnego ${ }^{1}$, sięgać mogą po różnorodne formy promocji — od reklam w tradycyjnych mediach, poprzez zastosowanie mediów społecznościowych, po tworzenie aplikacji na urządzenia mobilne, które dzięki wykorzystaniu geolokalizacji i zjawiska rzeczywistości rozszerzonej umożliwiają łączenie pozyskiwania informacji oraz usług. Na osiągnięty efekt składa się zarówno świadomość istnienia innowacyjnych i wciąż unowocześnianych narzędzi komunikacyjnych, jak i wola ich zastosowania. Administracja terenowa nie zajmuje pozycji lidera we wdrażaniu awangardowych przedsięwzięć w zakresie utrzymywania relacji $\mathrm{z}$ otoczeniem społecznym. W odróżnieniu od podmiotów komercyjnych — sensem istnienia samorządu terytorialnego jest wykonywanie zadań publicznych ${ }^{2}$, polegających na zaspokajaniu zbiorowych potrzeb wspólnoty samorządowej, a nie generowanie zysków. Stąd nierzadko działanie „urzędowe” nie jest kojarzone ze sprawnością, szybkością i skutecznością przekazu informacji. Coraz częściej jednak, urzeczywistniając ideę smart city, samorządy stają się aktywnym uczestnikiem rynku nowych technologii komunikacyjnych także w sferze polityki reklamowej.

${ }^{1}$ Zgodnie ze stanem na 1 stycznia 2019 r. kraj podzielony jest na 16 województw, 314 powiatów i 2477 gmin. Wśród gmin: 302 to gminy miejskie (a w tym 66 miast na prawach powiatu), 638 - to gminy miejsko-wiejskie oraz 1537 - to gminy wiejskie. Oczywiste jest istnienie dysproporcji $\mathrm{w}$ nakładach budżetowych przeznaczanych na działania promocyjne w związku z rodzajem jednostki samorządu terytorialnego. Zdecydowanie większe możliwości mają pod tym względem województwa samorządowe czy duże miasta na prawach powiatu niż pozostałe powiaty bądź gminy. Źródło danych liczbowych: Baza JST. Samorząd terytorialny $w$ Polsce. Pobrano z: http://administracja.mswia.gov.pl (data dostępu: 13.11.2019).

${ }^{2}$ Działania promocyjne stanowią zadanie własne gminy wyszczególnione $\mathrm{w}$ art. 7 , ust. 1, pkt. 18 Ustawy z dnia 8 marca 1990 roku o samorządzie gminnym (Dz.U. 1990, nr 16, poz. 95). Podobnie jest w przypadku powiatów, gdzie na podstawie art. 4 ust. 1 pkt. 21 Ustawy z dnia 5 czerwca 1998 roku o samorządzie powiatowym zadaniem publicznym o charakterze ponadgminnym jest promocja powiatu (Dz.U. 1998, nr 91, poz. 578). 


\section{Działania reklamowe w funkcjonowaniu samorządu terytorialnego}

Interpretacja leksykalna traktuje reklamę jako „działanie mające na celu zachęcenie potencjalnych klientów do zakupu konkretnych towarów lub do skorzystania z określonych usług"'3. Skłonienie odbiorców, aby wykonali określone działanie albo zachowali się w wyznaczony sposób, ma kluczowe znaczenie dla nadawców korzystających z kanałów reklamowych umożliwiających transmisję danych. By osiągnąc cel, wykorzystują metody pozwalające precyzyjnie dobrać narzędzie komunikacji — adekwatne do sytuacji oraz skierowane do właściwych grup odbiorców.

Podstawowym interesariuszem samorządu, a zarazem głównym adresatem przekazów perswazyjnych, są oczywiście mieszkańcy. Dokonując segmentacji audytorium, wskazać trzeba ponadto na istotne kategorie klientów zewnętrznych, jak na przykład: gości zainteresowanych produktem turystycznym, studentów korzystających z oferty edukacyjnej czy przedsiębiorców nabywających tereny inwestycyjne gminy lub powiatu. Oni wszyscy potencjalnie mogą zostać zachęceni do pożądanych przez samorząd zachowań właśnie dzięki reklamie.

Reklama, czyli specyficzna ze względu na cel i charakter treść aktu komunikacyjnego, definiowana jest przez Dyrektywę Parlamentu i Rady Unii Europejskiej jako ,przedstawienie [przekazu, treści — D.K.] w jakiejkolwiek formie w ramach działalności handlowej, gospodarczej, rzemieślniczej lub wykonywania wolnych zawodów w celu wspierania zbytu towarów lub usług, w tym nieruchomości, praw i zobowiązań"4. Z kolei zgodnie z definicją zawartą w Kodeksie Etyki Reklamy jest nią przekaz zawierający „W szczególności informację lub wypowiedź, zwłaszcza odpłatny lub za wynagrodzeniem w innej formie, towarzyszący czyjejkolwiek działalności, mający na celu zwiększenie zbytu produktów, inną formę korzystania z nich lub osiągnięcie innego efektu"s pożądanego przez reklamodawcę. W rozumieniu Kodeksu Etyki Reklamy, w analizowanym pojęciu reklamy nie mieszczą się trzy kategorie przekazów. Reklamą nie jest więc: (1) popularyzowanie zachowania społecznie pożądanego z zastrzeżeniem kryterium autopromocji upowszechniania przekazu ${ }^{6}$, (2) komunikowanie per-

${ }^{3}$ Definicja za Stownikiem języka polskiego PWN. Pobrano z: sjp.pwn.pl (data dostępu: 29.09.2019).

${ }^{4}$ Dyrektywa 2006/114/WE Parlamentu Europejskiego i Rady Europejskiej z dnia 12 grudnia 2006 r. dotycząca reklamy wprowadzającej w błąd i reklamy porównawczej (wersja ujednolicona). Opublikowana w Dzienniku Urzędowym Unii Europejskiej z 27 grudnia 2006 r. (CELEX: 32006L0114).

5 Art. 3 Kodeksu Etyki Reklamy według stanu na 18 stycznia 2018 r. Pobrano z: www. radareklamy.pl (data dostępu: 9.10.2019).

${ }^{6}$ Art. 3, pkt. a, poz. 1 Kodeks Etyki Reklamy głosi, że reklamą nie jest przekaz „mający na celu propagowanie pożądanych społecznie zachowań, jeżeli nie jest jednocześnie związa- 
swazyjne w kampaniach wyborczych i referendalnych oraz (3) działania wynikające $\mathrm{z}$ obowiązków informacyjnych wymaganych prawem ${ }^{7}$. Ustawa regulująca funkcjonowanie rynku mediów elektronicznych precyzuje natomiast, że „reklamą jest przekaz handlowy, pochodzący od podmiotu publicznego lub prywatnego, w związku z jego działalnością gospodarczą lub zawodową, zmierzający do promocji sprzedaży lub odpłatnego korzystania z towarów lub usług; reklamą jest także autopromocja"s.

Podejmując aspekt definicyjny, warto jednocześnie zwrócić uwagę na to, że „reklamy można ujmować w dwóch aspektach — szerokim i wąskim. Pierwszy z nich odnosi się do wszelkich starań zmierzających do upowszechnienia określonych informacji o ludziach, firmach, ideach, przedsięwzięciach lub rzeczach w celu ich popularyzacji, wzbudzania zainteresowania nimi. Sa to działania określane przede wszystkim mianem reklamy społecznej, ale w definicji tej mieści się również reklama polityczna. Reklama w wąskim ujęciu to reklama gospodarcza" (Harasimiuk, 2011, s. 26).

W przypadku administracji terenowej pamiętać trzeba, że „umocnienie i rozwój idei samorządności i instytucji samorządu terytorialnego zależą od odpowiedniego kierunku zmian w mentalności społecznej i mentalności politycznej" (Izdebski, 2011, s. 18). Rezultatem działalności reklamowej może być więc szeroko pojmowane „wspieranie i upowszechniania idei samorządowej” czy „pobudzanie aktywności obywatelskiej”, co ważne jest nie tylko z punktu widzenia marketingowego, ponieważ „pielęgnowanie i wspieranie działań oddolnych, inicjatyw społeczności lokalnych i organizacji pozarządowych, aktywności społeczeństwa obywatelskiego. Na tym poziomie bowiem zmiany są najistotniejsze, wpływają w zasadniczy sposób na całokształt implementacji założeń zrównoważonego rozwoju" (Kuzior, 2014, s. 98). Oprócz warstwy ideowej liczy się oczywiście także przeprowadzanie konkretnych przedsięwzięć, jak na przykład zbywanie terenów inwestycyjnych, stymulacja budownictwa mieszkaniowego, pozyskiwanie przedsiębiorców tworzących nowe miejsca pracy, zwiększanie zainteresowania ofertą gminnych lub powiatowych obiektów sportowych, rekreacyjnych, medycznych, kulturalnych itd. Reklama służy więc poprawie skuteczności realizacji zadań samorządu terytorialnego.

ny z promocją reklamodawcy, przedmiotu jego działalności, jego produktu lub produktów pozostających w jego dyspozycji".

7 Dotyczy podmiotu zobligowanego do działań komunikacyjnych obowiązującymi przepisami lub przekazu, który od takiego nadawcy jest ,skierowany do jego organów, udziałowców lub potencjalnych udziałowców".

8 Art. 4 pkt. 17 Ustawy z dnia 29 grudnia 1992 r. o radiofonii i telewizji (Dz.U. 1993, nr 7, poz. 34).

9 Działania te zawarte są w ustawowym katalogu zadań własnych gminy. w art. 7, ust. 1, pkt. 17 Ustawy z dnia 8 marca 1990 r. o samorządzie gminnym. 
Pracownicy administracji terenowej, prowadząc działalność reklamową, muszą uwzględniać ponadto między innymi konstytucyjne wskazania dotyczące ochrony przez władze publiczne „konsumentów, użytkowników i najemców przed działaniami zagrażającymi ich zdrowiu, prywatności i bezpieczeństwu oraz przed nieuczciwymi praktykami rynkowymi”'10, w tym nieuczciwą lub niedozwoloną reklamą, której zleceniodawcą oczywiście nie może być gmina czy powiat. Dlatego jednostki samorządu muszą wyjątkowo poważnie traktować sprawę przestrzegania wymogów etycznych. Wiele komercyjnych podmiotów rynku reklamy pozwala sobie na więcej swobody w poszczególnych działaniach reklamowych, nawet mając świadomość istnienia ugruntowanych wieloletnią tradycją unormowań, bo przecież „międzynarodowy kodeks etyczny reklamy, przygotowany przez Izbę Handlową w Paryżu w 1939 r. i obowiązujący z pewnymi zmianami do dziś, jest najstarszym kodeksem regulującym działalność reklamową" (Słowik, 2012, s. 82).

Warto podkreślić, że nadzór nad praworządnością funkcjonowania samorządu sprawuje administracja rządowa, a w sferze finansowej — regionalne izby obrachunkowe (Dolnicki, 2019). Nie oznacza to, że mają one możliwość ingerencji nadzorczych w samodzielność samorządu terytorialnego spowodowanych na przykład negatywną oceną zasadności albo formy podejmowanych działań (w tym ze sfery komunikacji perswazyjnej).

\section{Administracja lokalna jako podmiot rynku reklamowego}

Jednostce samorządu terytorialnego konstytucyjnie zagwarantowano samodzielność w realizacji ustawowych zadań ${ }^{11}$. Dotyczy to również zadań własnych w zakresie promocji. Weryfikacji, ze strony organów nadzoru ${ }^{12}$, podlega formalna zgodność z przepisami wydatkowania środków publicznych przeznaczanych na promocję, lecz dobór narzędzi komunikacyjnych służących osiągnięciu wyznaczonych celów leży w gestii administracji terenowej, której aktywność promocyjną kategoryzować można na wiele sposobów. Z punktu widzenia zaangażowania mass mediów polega ona na działaniach wykorzystujących środki

${ }^{10}$ Art. 76 Konstytucji RP (Dz.U. 1997, nr 78, poz. 483).

11 Art. 171 Konstytucji RP stanowi, że „działalność samorządu terytorialnego podlega nadzorowi z punktu widzenia legalności”. Natomiast organami nadzoru nad działalnością jednostek samorządu terytorialnego są: „Prezes Rady Ministrów i wojewodowie, a w zakresie spraw finansowych regionalne izby obrachunkowe”.

12 Podstawy prawne do działań nadzorczych zawarte są w ustawach: art. 85-102 Ustawy z dnia 8 marca 1990 r. o samorządzie gminnym oraz art. 76-90 Ustawy z dnia 5 czerwca 1998 r. o samorządzie powiatowym. 
masowego przekazu albo bezpośrednio skierowanych do adresatów. Można ją również postrzegać jako ukierunkowaną na środowisko wirtualne bądź świat realny. Po wprowadzeniu jako kryterium podziału konieczności przekazywania środków finansowych - będą to przedsięwzięcia wymagające zaangażowania budżetowego samorządu lub realizowane poza systemem finansów publicznych. Analiza przedsięwzięć przez pryzmat potrzeb odbiorców wskazuje na projekty masowe bądź też skierowane do poszczególnych grup docelowych. Ze względu na zasięg społeczny wyróżniamy na przykład programy: sublokalne, sektorowe, ogólne. Segmentacja ze względu na nadawców pozwoli wyodrębnić akcje bezpośrednio realizowane przez samorząd lub zlecone podmiotom zewnętrznym. W praktyce władz lokalnych dominują działania mieszane, gdzie uwzględniać należy efekty całościowe, wypracowane nawet w ramach dążenia do osiągnięcia wyodrębnionego celu promocyjnego.

Bezsprzecznie jednak samorządy są podmiotami zainteresowanymi prowadzeniem działalności reklamowej. Nawet niewielkie gminy dysponują ,produktem", którego promocja przynosi wymierne korzyści wspólnocie lokalnej. Dotyczy to między innymi obiektów turystycznych, zabytków, infrastruktury rekreacyjnej czy wydarzeń kulturalnych lub sportowych. Im większa gmina, powiat, a na pewno już miasto na prawach powiatu, tym bardziej do samorządu odnosić wolno sformułowanie, że ,organizacja nie może funkcjonować na rynku bez uprawiania reklamy, niezależnie od tego, czy dotyczy to reklamy zinstytucjonalizowanej (outdoor, TV, radio, Internet), czy niezinstytucjonalizowanej (plotka, ambient, polecenie itp.). Brak reklamy powoduje brak możliwości powstania znaczeń i komunikacji o organizacji. Brak znaczeń i komunikacji wyklucza organizację ze społecznego funkcjonowania, co w praktyce przekłada się na niemożność uczestniczenia w rynku” (Wszołek, 2016, s. 26). Zagrożenie takie oczywiście nie dotyczy wprost samorządu jako struktury o charakterze korporacyjnym, lecz wpływać może na skuteczność jej funkcjonowania.

\section{Determinanty polityki reklamowej samorządu}

Samorząd, chociaż autonomiczny w opracowywaniu strategii komunikacyjnych, powinien implementować $\mathrm{w}$ dokument planistyczne rozwiązania wynikające z postępu technologicznego. W rzeczywistości gospodarczej „migracja budżetów reklamowych do internetu powoduje nie tylko rozwój form reklamowych, ale także jest determinantą wyszukanych rozwiązań tematycznych i jakościowych w komunikacji online. Przyszłość reklamy z pewnością należy do urządzeń osobistych, które towarzyszą ludziom przez cały czas. Smartfon jest najlepszym narzędziem nie tylko z uwagi na osobisty charakter urządzenia, ale 
także na możliwości geolokalizacji, a także korzystania z potencjału możliwości aplikacyjnych i wykorzystaniem mediów społecznościowych" (Chmielewska, 2016, s. 68). Ten potencjał administracja terenowa jest w stanie spożytkować w swoich działaniach promocyjnych. W typologii działań reklamowych samorządu terytorialnego $\mathrm{w}$ środowisku wirtualnym wyodrębniać można przedsięwzięcia udostępniane na: (1) własnych prezentacjach internetowych ${ }^{13}$, (2) nośnikach podmiotów zależnych, powiązanych i współpracujących, (3) portalach i profilach środków masowego przekazu, (4) innych nośnikach. Tam upowszechniane są różnego rodzaju formy komunikacji perswazyjnej.

Samorząd przyjmując procedury realizacji zadań promocyjnych, powinien zakładać potrzebę ich cyklicznej weryfikacji w celu uwzględnienia kierunków przemian systemu komunikacji perswazyjnej, zwłaszcza gdy wymaga to wyasygnowania funduszy publicznych. Dlatego koncentrując się na możliwościach cyberprzestrzeni, nie wolno zapominać o innych nośnikach, ponieważ na przykład „firma Marketingcharts.com opublikowała wyniki badań, według których aż 57\% studentów nigdy nie klika reklam internetowych, a 30\% nigdy nawet nie spogląda na nie. Dodatkowo 56\% badanych stara się unikać pojawiających się reklam online" (Rachwał, 2019, s. 31). Przedstawiciele administracji lokalnej muszą uwzględniać zmiany zachodzące w środowisku komunikacyjnym, a także szeroko rozumiane przekształcenia sposobów działań ze sfery CRM (ang. customer relationship management). Jednostki samorządu terytorialnego również dotyczy wymóg elastycznego dostosowywania się do nowych zjawisk odczuwalnych przez podmioty komercyjne, gdy ,zmiany społeczne, jakie obecnie zachodzą, związane z pojawieniem się nowych potrzeb wyższego rzędu (np. rozrywką, technologią, nauką), przekształceniem form komunikacji, możliwością szybkiego przemieszczania się i podróżowania, wszechobecnością reklam, zmniejszającym się zaufaniem (do mediów tradycyjnych, instytucji publicznych, organizacji pozarządowych i jednostek), a także rosnącą nieufnością, sceptycyzmem, brakiem wiary $\mathrm{w}$ innych, jak i siebie, wymuszają na przedsiębiorcach modyfikację podejścia do współpracowników i konsumentów. Modyfikacja ta dotyczy sposobu budowania i utrzymywania relacji z odbiorcami, czyli zarządzania relacjami z klientem" (Jankowska, 2018, s. 247). Aktywność komunikacyjna samorządów przypominać musi postępowanie podmiotów zorientowanych na osiągnięcie sukcesu w strukturach innowacyjnej gospodarki. Oznacza to konieczność adaptowania w obszarze lokalnym nowatorskich rozwiązań z innych poziomów i rodzajów komunikacji. W sferze wykonywania zadań publicznych wdrażać należy nowoczesne instrumenty sprawdzone już w działalności reklamowej. Przypominając niezwykle popularną grę „Pokémon GO” dostarczoną przez firmę Niantica, warto wskazać na możliwości tkwiące w rzeczywistości

${ }^{13}$ Dotyczy to stron internetowych gmin i powiatów, ale również profili samorządu w mediach społecznościowych, kanałów filmowych, aplikacji na urządzenia mobilne itp. 
rozszerzonej (ang. augmented reality), która „może stanowić skuteczny kanał komunikacji marketingowej z konsumentami podróżującymi pomiędzy światem online i offline oraz może być odpowiedzią na zmiany naznaczone efektem $\mathrm{ROPO}^{14}$. AR pozwala nanosić interaktywne obiekty wirtualne na obraz świata fizycznego w czasie rzeczywistym. Mogą to być zarówno treści tekstowe, jak i obrazy, filmy, trójwymiarowe modele oraz hiperłącza do zewnętrznych witryn" (Bekus, 2018, s. 293). Narzędzie wydaje się interesującym instrumentem służącym promocji samorządowych instytucji sportu, kultury, służby zdrowia czy turystyki realizujących przecież zadania publiczne na rzecz wspólnoty lokalnej.

Samorząd obowiązują oczywiście granice ekspansji, wyznaczane chociażby przez normy etyczne, gdyż „wszechobecność reklam oraz negatywny stosunek odbiorców do tego typu komunikacji zmuszają reklamodawców do ciągłego poszukiwania nowych sposobów dotarcia do potencjalnych klientów. Dążenie do zaskoczenia odbiorcy oraz przykucia jego uwagi może się łączyć z przekraczaniem pewnych granic - prawnych bądź obyczajowych" (Barczyk-Sitkowska, 2017, s. 148). Nie jest to jednak ścieżka, którą powinna podążać administracja publiczna. Być może tylko w przypadku tzw. marketingu społecznego można $\mathrm{z}$ aprobatą podejść do przełamywania konwencji promocyjnych $\mathrm{w}$ formie prezentowania zjawisk, wydarzeń czy emocji, by osiągnąć cel wyższego rzędu. Warto zaznaczyć, że wspomniany marketing społeczny ,jest odrębną dyscypliną marketingu od 1970 roku. Odnosi się prawie do wszystkich działań mających na celu zmianę postaw lub zachowań społeczeństwa. To sposób zarządzania produktami materialnymi i abstrakcyjnymi, czyli ideami. W tym celu wykorzystuje systematyczny proces planowania zasad i technik marketingowych, koncentruje się na priorytetowych segmentach docelowych odbiorców w celu dostarczania pozytywnych korzyści dla społeczeństwa" (Tkocz, 2016, s. 26). To również sfera aktywności komunikacyjnej, która może i powinna być podejmowana przez jednostki samorządu terytorialnego.

\section{Formy działań reklamowych administracji samorządowej}

W gestii samorządu terytorialnego, podejmującego aktywność reklamową, jest przede wszystkim wybór jej rodzaju. Tradycyjnie są to działania w środkach masowego przekazu (prasa, radio, telewizja) oraz przedsięwzięcia wyko-

${ }^{14}$ Efekt ROPO (ang. Research Online Purchase Offline) polega na uwzględnianiu w zachowaniach konsumenckich działań z wykorzystaniem cyberprzestrzeni do pozyskania informacji i opinii o produkcie przed jego fizycznym zakupem. 
rzystujące materiały poligraficzne (np. ulotki, broszury, foldery, plakaty, billboardy). Obecnie kanonem stały się też prezentacje w środowisku wirtualnym. Do najprostszych zalicza się reklamę w klasycznych formatach dostępnych na stronach internetowych. Wyróżniające się na tle zawartości informacyjnej danego nośnika: zdjęcia, galerie, infografiki, animacje czy nawet, irytujące większość użytkowników, pop-upy stanowią już konwencjonalny środek przekazu treści promocyjnych. Nagromadzenie podobnych narzędzi przekazu osłabia ich efektywność, a „w związku z zagęszczeniem różnorodności produktów i idącą $\mathrm{z}$ tym w parze nadwyżką informacji konsumentowi coraz trudniej zdecydować się na wybór spośród stojących przed nim możliwości. Tylko ciekawa, kreatywna, odmienna, przekonująca komunikacja może skierować jego uwagę na produkt. Ten produkt trzeba opakować w reklamę. Opakować można go w już znane, ale też nieznane jeszcze opakowania, które trzeba będzie wynaleźć" (Płuchowska, 2017, s. 457). Dlatego popularność zyskuje reklama natywna. „Słowo »natywny« oznacza »taki jak w warunkach naturalnych«. Dlatego też uważa się, że reklama natywna nie powinna być nachalna tylko naturalnie wpleciona w treść lub obraz artykułu, delikatna, subtelna. Może przybierać postać tekstu, zdjęcia, grafiki, treści video, tzw. »captcha«, przez co widoczna może być wszędzie, od prasy drukowanej po wszelkie komunikaty w sieci, social media. Kolejnym ważnym elementem reklamy natywnej jest fakt, że powinna także pasować do charakteru zamieszczanych treści w danym medium, zarówno pod względem wizualnym jak i treści" (Chrąchol-Barczyk, 2018, s. 141). Reklama natywna dostępna jest w ofercie agencji reklamowych. Największe serwisy internetowe, jak ONET.pl, zachwalają takie rozwiązanie: ,[...] reklama natywna jest jak kameleon, który przystosowuje się do otoczenia, w którym się znajduje. Nie drażni, nie irytuje, nie narzuca się odbiorcom. Znajduje się we właściwym miejscu i czasie, jest potencjalnie interesująca i pomocna — po prostu użyteczna. Za jej wysoką jakością stoją redaktorzy kreatywni, którzy tworzą teksty we współpracy z partnerami i wydawcami"'15.

W przypadku promocji samorządu często wskazywana jest też dodatkowa podkategoria reklamy natywnej stanowiąca potencjalne zagrożenie, czyli reklama polityczna lub promująca jednoosobowe ograny władzy lokalnej ${ }^{16}$. Szczególnie wyrazista bywa podczas kampanii wyborczych. Formą reklamy klasyfikowanej jako natywna mogą być różnego rodzaju zestawienia, sondaże, pozytywne wypowiedzi dotyczące przedstawicieli urzędujących władz. Oczywiście nie dotyczy to wyłączenie środowiska wirtualnego. Biorąc pod uwagę media tradycyjne, a szczególnie publikacje w prasie samorządowej, akcentowane są na przykład przypadki prezentacji postaci kontrkandydatów, gdzie cechy

15 Informacja z działu ONET.REKLAMA poświęconego reklamie natywnej. Pobrano z: serwis: reklama.onet.pl (data dostępu: 11.10.2019).

${ }^{16}$ Jednoosobowym organem gminy jest wójt, burmistrz lub prezydent miasta. 
reklamy natywnej będą publikowane w specyficznym (nawet zmanipulowanym) kontekście oraz $\mathrm{w}$ dostosowanej do potrzeb reklamodawcy formie ilustracji fotograficznych, a „przykłady reklamy natywnej świadczą o tym, że redakcje wykorzystują gazety jako kanał budowania wizerunku urzędującego prezydenta, przy jednoczesnym kontestowaniu wizji miasta proponowanych przez jego politycznych przeciwników. Co ciekawe, wywiady z redaktorami ujawniły, że wykorzystanie łamów gazet samorządowych do prowadzenia kampanii wyborczej nie jest przez nich identyfikowane $z$ treściami politycznymi. To może oznaczać, że redaktorzy utożsamiają się z przekazami, które sygnują własnymi nazwiskami, wypierając jednocześnie ich polityczny charakter" (Piechota, 2016, s. 81). Podobne przekazy krok już dzieli nie tylko od reklamy krytycznie oceniającej sytuację, lecz wręcz negatywnej. Nadmierna fascynacja reklamą natywną rodzi niekiedy zagrożenie upowszechnianiem dezinformacji. Szczególnie dotyczy to kreacji zakładających eliminację wyraźnego wyróżnienia i zaakcentowania odrębności treści reklamowej od redakcyjnej. Stąd jednym z wyodrębnionych typów fake newsów jest właśnie specyficznie udostępniana reklama „wykorzystywana do opisania materiałów reklamowych pod postacią autentycznych wiadomości, a także do odsyłania do komunikatów prasowych opublikowanych jako wiadomości” (Bąkowicz, 2019, s. 286).

Efektywna w kategoriach celów stawianych marketingowi terytorialnemu wydaje się również na przykład reklama porównawcza. Cytowany Kodeks Etyki Reklamy definiuje ją jako „reklamę, która umożliwia rozpoznanie konkurenta lub jego produktów, lub produktów pozostających w jego dyspozycji w celu promowania innego podmiotu, lub jego produktów, lub produktów pozostających w jego dyspozycji” ${ }^{17}$. Natomiast „reklama porównawcza” w ujęciu dyrektywy Parlamentu Europejskiego i Rady Europejskiej oznacza „każdą reklamę, która wyraźnie lub przez domniemanie identyfikuje konkurenta albo towary lub usługi oferowane przez konkurenta” przy czym „reklama porównawcza, o ile porównuje ona cechy zasadnicze, istotne, weryfikowalne i reprezentatywne i jeśli nie wprowadza w błąd, może być w pełni uprawnionym środkiem informowania konsumentów na temat tego, co jest dla nich korzystne"18. Reklama porównawcza znajduje zastosowanie nie tylko w materiałach z zakresu promocji inwestycyjnej, ale też komunikacji z mieszkańcami. Wykorzystuje „,zrelatywizowane fakty i liczby potwierdzające szczególną (wyższą) atrakcyjność miasta w stosunku do miast konkurencyjnych. $Z$ reguły informacje takie dotyczą wyników konkursów, rankingów, ocen i wyróżnień potwierdzających zweryfikowaną obiektywnie wysoką pozycję miasta wśród innych miast" (Szromnik, 2015, s. 104).

17 Art. 3 Kodeksu Etyki Reklamy. Pobrano z: www.radareklamy.pl (data dostępu: 9.10.20119).

${ }_{18}$ Dyrektywa 2006/114/WE Parlamentu Europejskiego i Rady Europejskiej z dnia 12 grudnia 2006 r. dotycząca reklamy wprowadzającej w błąd i reklamy porównawczej (CELEX: 32006L0114). 


\section{Nośniki treści reklamowych znajdujące się w dyspozycji samorządu}

Po wprowadzeniu kryterium podziału działalności reklamowej ze względu na wykorzystanie środków masowego przekazu okazuje się, że jednostki samorządu terytorialnego tworzą odrębną strukturę w postaci prasy lokalnej. Zgodnie z obowiązującymi przepisami wydają zarejestrowane czasopisma, które w powszechnej praktyce nie wypełniają wszystkich funkcji mass mediów, lecz od trzech dekad obecne są na rynku medialnym. Prasa samorządowa, w aktualnych rozwiązaniach prawnych, nie jest w stanie skutecznie sprawować funkcji kontrolnej nad władzami gmin lub powiatów. Mimo to stanowi nośnik regularnie dostarczający mieszkańcom informacji dotyczących wydarzeń istotnych w wymiarze sublokalnym i lokalnym. Czasopisma samorządowe umożliwiają również prowadzenie komunikacji perswazyjnej. Dotyczy to zarówno formuły przedstawiania upowszechnianych treści, zgodnie z linią programową zakładającą kształtowanie pozytywnego wizerunku miejscowości, jak i - przynajmniej w części tytułów - bezpośredniego upubliczniania płatnych lub darmowych ogłoszeń.

Kolejną sferą aktywności reklamowej administracji terenowej są media dostępne w cyberprzestrzeni - od portali redakcji prasy samorządowej, poprzez strony internetowe gmin, miast i powiatów, po media społecznościowe zarządzane przez urzędników. W badaniu wykonanym jesienią 2019 roku $^{19}$ ustalono, że społeczny zasięg facebookowych profili samorządowych $\mathrm{w}$ miastach wojewódzkich zestawiony z liczbą mieszkańców wynosił prawie 40\% (39,2\%) łącznej populacji tych miast. Oczywiście wszystkie badane duże ośrodki miejskie prowadziły działania komunikacyjne z zastosowaniem serwisu Facebook. Tymczasem równolegle wykonana analiza ${ }^{20}$ na terenie 41 gmin pierwszego ustawowo wyodrębnionego w Polsce obszaru metropolitalnego ${ }^{21}$ pozwoliła stwierdzić

${ }_{19}$ Badanie własne autora przeprowadzone w październiku 2019 r. w miastach wojewódzkich obejmowało siedziby administracji rządowej i samorządowej, czyli Bydgoszcz i Gorzów Wielkopolski (urzędy wojewódzkie) oraz Toruń i Zieloną Górę (urzędy marszałkowskie).

20 Badanie własne autora mające na celu ustalenie poziomu zastosowania mediów społecznościowych przez jednostki samorządu terytorialnego zostało zrealizowane w październiku 2019 r. na obszarze obejmującym Górnośląsko-Zagłębiowską Metropolię, czyli: Będzin, Bieruń, Bobrowniki, Bojszowy, Bytom, Chełm Śląski, Chorzów, Czeladź, Dąbrowa Górnicza, Gierałtowice, Gliwice, Imielin, Katowice, Knurów, Kobiór, Lędziny, Łaziska Górne, Mierzęcice, Mikołów, Mysłowice, Ożarowice, Piekary Śląskie, Pilchowice, Psary, Pyskowice, Radzionków, Ruda Śląska, Rudziniec, Siemianowice Śląskie, Siewierz, Sławków, Sosnowiec, Sośnicowice, Świerklaniec, Świętochłowice, Tarnowskie Góry, Tychy, Wojkowice, Wyry, Zabrze, Zbrosławice.

${ }^{21}$ Ustawa z dnia 9 marca 2017 r. o związku metropolitalnym w województwie śląskim (Dz.U. 2017, poz. 730). 
spadek poziomu wykorzystania social mediów w sytuacji, gdy pole badawcze składało się z gmin różnej wielkości. Zastosowanie przez samorządy oficjalnego profilu w serwisie Facebook wynosiło tam prawie 88\% (87,8\%), a ich łączny społeczny zasięg nie przekraczał 17\% (16,5\%) populacji. Rozwój technik komunikacyjnych w środowisku wirtualnym pozwala prognozować jednak wzrost liczby użytkowników również w przypadku małych jednostek samorządu terytorialnego.

Zjawiskiem charakterystycznym dla nośników bezpośrednio lub pośrednio związanych z samorządem jest też efekt synergii komunikacyjnej. Polega on na wzajemnym wzmacnianiu przekazów urzędu, instytucji kultury, sportu, rekreacji, placówek medycznych, stowarzyszeń i organizacji wspierających administrację lokalną, a także między innymi spółek będących własnością samorządu lub z nim powiązanych (zarządy dróg, wodociągi, przedsiębiorstwa energetyki cieplnej, zakłady oczyszczania miast itd.).

W sferze mediów należących do samorządów, od nich zależnych lub z nimi współdziałających kwestia publikacji reklam, zgodnych ze strategią komunikacyjną administracji terenowej, ma wyłącznie wymiar techniczny. Publikowanie takich treści jest stosowaną praktyką, chociaż uwzględnia specyfikę konkretnych nośników. W Polsce nie przyjęto bowiem przepisów regulujących zamieszczanie materiałów promocyjnych w mediach samorządowych. Sprawujące nadzór nad gospodarką finansową samorządów regionalne izby obrachunkowe również nie wypracowały spójnego stanowiska w tej kwestii, a nawet wydawały sprzeczne uchwały. I tak „Regionalna Izba Obrachunkowa w Rzeszowie jeszcze w 1998 r. sprzeciwiała się możliwości ukazywania się ogłoszeń płatnych w prasie samorządowej. W następnych latach podobne stanowisko wyrażały izby w Łodzi oraz Wrocławiu. Przeciwnego zdania była Regionalna Izba Obrachunkowa w Opolu" (Krawczyk, 2017, s. 57). Uznała ona w 2015 roku, że prasa samorządowa działa zgodnie z identycznymi regułami jak inne periodyki, a więc może zamieszczać ogłoszenia płatne. Wiele samorządów przyjęło więc zasadę, że nie ma możliwości publikacji reklam, jeśli wydawcą czasopisma jest bezpośrednio organ gminy lub urząd miejski. Natomiast, gdy gazeta ukazuje się staraniem instytucji gminnej lub spółki zależnej, to upowszechnia płatne treści promocyjne. Reguły oddolnie przyjęte przez daną jednostkę samorządu terytorialnego są przez nią przestrzegane. Norma uzależniająca publikację ogłoszeń od „urzędowego" charakteru wydawcy nie jest jednak powszechna. Pod tym względem panuje dowolność, a zasady obowiązujące w danej gminie lub powiecie ustanawia władza lokalna. Dlatego zresztą słuszne wydają się postulaty promotorów nowego podejścia badawczego do mediów samorządowych. Między innymi ze względu na odrębność mediów samorządowych „pojawianie się wielu wątpliwości prawnych oraz zagrożenie powstawania konfliktów interesów wystarczająco uzasadniają konieczność rozważenia ich roli jako nowej, odrębnej podmiotowości systemu medialnego" (Kowalik, 2018, s. 447). 


\section{Podsumowanie}

Samorządy w klasyfikacji budżetowej22 corocznie wyszczególniają nakłady na promocję. Biorąc pod uwagę tylko największe polskie ośrodki miejskie (miasta wojewódzkie) w okresie trzech kolejnych lat (2016, 2017 i 2018), spadek wydatków na ten cel odnotowano zaledwie w przypadku $13 \%$ badanych jednostek samorządu terytorialnego. Konsekwentny wzrost ujawniono natomiast w budżetach $40 \%$ miast. Pozostałe (46\%) wskazywały zmienną wysokość środków. Chociażby właśnie ze względu na zaangażowanie funduszy publicznych polityka promocyjna $\mathrm{w}$ jednostce samorządu terytorialnego powinna być traktowana systemowo. Poszczególne działania reklamowe wynikać muszą ze strategii precyzującej nie tylko cele do osiągnięcia, ale również perspektywę czasową oraz stosowane narzędzia komunikacyjne. Podobnie jak w gospodarce, gdzie ,połączenie technologii teleinformatycznych, przemysłu i internetu rzeczy leży u podstaw koncepcji Przemysł 4.0. Pojęcie, które zostało wprowadzone w 2011 r. przez Henninga Kagermanna, profesora fizyki i byłego prezesa zarządu SAP, przekształciło się w strategię rozwoju niemieckiego przemysłu", która zakłada, że „obniżenie kosztów, poprawa wydajności, a także oferowanie udoskonalonych produktów i usług uwzględniających preferencje i zachowania konsumentów mają być osiągane dzięki automatyzacji produkcji, opartej na wykorzystaniu i wymianie danych w czasie rzeczywistym, przy użyciu sztucznej inteligencji (ang. artificial intelligence)" (Pieriegud, 2016, s. 21-22). W przypadku samorządu aktywność wynikająca ze strategii promocyjnej objawiać się powinna więc nie tylko w kampaniach reklamowych, lecz również w świadczeniu usług publicznych, marketingowo pojmowanej otwartości wobec interesariuszy czy stałej orientacji na poprawę jakości funkcjonowania. Zintegrowane podejście dotyczy też stosowanych narzędzi komunikacyjnych. Dzięki wykorzystaniu nowoczesnych i spójnych rozwiązań, całościowo odnoszących się do przedstawiania działalności administracji terenowej, można przy utrzymywaniu relacji społecznych osiągać cele zarówno produktowe (krótkoterminowe zadanie kampanii reklamowej), jak i wizerunkowe (długookresowe przekształcenia w postrzeganiu organizacji). Dlatego nawet na szczeblu gminy lub powiatu przekazy reklamowe muszą być zaplanowane, w miarę technologicznych możliwości zindywidualizowane oraz upowszechniane z uwzględnieniem wymogu ewaluacji efektów służących optymalizacji całego procesu.

${ }^{22}$ W klasyfikacji budżetowej promocja jednostek samorzadu terytorialnego ujmowana jest w rozdziale 75075 . 
Tabela 1

Nakłady miast wojewódzkich (bez Warszawy) na promocję w PLN zgodnie z klasyfikacją budżetową (rozdział 75075) z określeniem trendu w wydatkach budżetowych gminy

\begin{tabular}{|l|r|r|r|c|}
\hline \multirow{2}{*}{ Miasto } & \multicolumn{3}{|c|}{ Lata } & \multirow{2}{*}{ Trend } \\
\cline { 2 - 4 } & 2016 & \multicolumn{1}{c|}{2017} & 2018 & \\
\hline Wrocław & 23677816,68 & 12841193,86 & 14140949,25 & Z \\
\hline Szczecin & 6515863,00 & 5289774,00 & 4402079,00 & S \\
\hline Gdańsk & 22949793,00 & 29004511,00 & 30467342,00 & W \\
\hline Opole & 2328694,94 & 3152044,90 & 2222697,17 & Z \\
\hline Katowice & 17762991,65 & 20986223,87 & 26265476,03 & W \\
\hline Zielona Góra & 3519628,46 & 1633751,03 & 4231658,51 & Z \\
\hline Poznań & 4794150,66 & 5733320,24 & 7672124,84 & W \\
\hline Kraków & 12910472,00 & 15837724,00 & 20238315,00 & W \\
\hline Olsztyn & 4711130,75 & 3717233,28 & 3592511,78 & S \\
\hline Białystok & 3630024,00 & 3442687,00 & 3990881,00 & Z \\
\hline Bydgoszcz & 12998613,95 & 9843794,25 & 12324653,08 & Z \\
\hline Rzeszów & 4280545,34 & 5949627,27 & 6802732,82 & W \\
\hline Lublin & 6815286,00 & 8968508,00 & 7641949,00 & Z \\
\hline Kielce & 7567289,04 & 10459724,59 & 8345294,67 & Z \\
\hline Lódź & 8476804,11 & 12055275,60 & 12839230,19 & W \\
\hline
\end{tabular}

Objaśnienia: W — konsekwentny wzrost od roku 2016 do roku 2018; S — systematyczny spadek; $\mathrm{Z}$ - zmienność nakładów w latach objętych badaniem

Źródło: Opracowanie własne na podstawie budżetów miast opublikowanych w Biuletynie Informacji Publicznej:

https://bip.um.wroc.pl/artykuly/322/budzet-miasta; http://bip.um.szczecin.pl/chapter_11073.asp; https:// bip.gdansk.pl/urzad-miejski/budzet-miasta,a,15; https://www.bip.um.opole.pl/?id=42684; https://bip.kato wice.eu/finanse/default.aspx; https://bip.zielonagora.pl/202/Budzet_miasta/; https://bip.poznan.pl/bip/bu dzet-miasta-poznania,lib,1003/; https://www.bip.krakow.pl/?id=42; http://bip.olsztyn.eu/bip/folder/3159/ budzet_miasta/; https://www.bip.bialystok.pl/finanse/budzet_miasta/; https://bip.um.bydgoszcz.pl/finan se/budzet_miasta_bydgoszcz/; https://bip.erzeszow.pl/361-finanse-miasta-rzeszowa/4949-2020-rok. html; https://bip.lublin.eu/finanse-i-majatek/budzet-miasta/2019/; http://www.bip.kielce.eu/podglad/-/ asset_publisher/BAkP/content/23-budzet-miasta-kielce/; https://bip.uml.lodz.pl/wladze/rada-miejska-w -lodzi/projekt-budzetu-miasta-lodzi/ (data dostępu: 20.11. 2019).

\section{Bibliografia}

Barczyk-Sitkowska, A., (2019). Reklama nieetyczna - studium przypadku Reserved („Polish boy wanted"). Studia Medioznawcze nr 2, s. 147-159.

Baza JST. Samorząd terytorialny $w$ Polsce. Pobrano z: http://administracja.mswia.gov.pl (data dostępu: 13.11.2019). 
Bąkowicz, K., (2019). Wprowadzenie do definicji i klasyfikacji zjawiska fake newsa. Studia Medioznawcze $n r 3$ (78), s. 280-289.

Bekus, T., (2018). Wykorzystanie rzeczywistości rozszerzonej w marketingu. Zeszyty Naukowe Wyższej Szkoty Humanitas. Zarzadzanie z. 3, s. 279-296.

Chmielewska, A., (2016). Przyszłość reklamy online. W: A. Wiśniewska, A. Kozłowska (red.), Reklama i PR z perspektywy wspótczesnych problemów komunikacji marketingowej (s. 53-70). Warszawa: Wyższa Szkoła Promocji, Mediów i Show Businessu.

Chrąchol-Barczyk, U., (2018). Reklama natywna i jej implikacja dla konsumentów. Handel Wewnętrzny $n r$ 4, s. 139-149.

Dolnicki, B., (2019). Samorzad terytorialny. Warszawa: Wolters Kluwer.

Dyrektywa 2006/114/WE Parlamentu Europejskiego i Rady Europejskiej z dnia 12 grudnia 2006 roku dotycząca reklamy wprowadzającej w błąd i reklamy porównawczej (wersja ujednolicona). Opublikowana w Dzienniku Urzędowym Unii Europejskiej z 27 grudnia 2006 roku. (CELEX:32006L0114).

Harasimiuk, E., (2011). Zakazy reklamy towarów w prawie europejskim i polskim. Warszawa: Wolters Kluwer.

http://bip.olsztyn.eu/bip/folder/3159/budzet_miasta/ (data dostępu: 20.11. 2019).

http://bip.um.szczecin.pl/chapter_11073.asp (data dostępu: 20.11. 2019).

https://bip.erzeszow.pl/361-finanse-miasta-rzeszowa/4949-2020-rok.html (data dostępu: 20.11. 2019).

https://bip.gdansk.pl/urzad-miejski/budzet-miasta,a,15 (data dostępu: 20.11. 2019).

https://bip.katowice.eu/finanse/default.aspx (data dostępu: 20.11. 2019).

https://bip.lublin.eu/finanse-i-majatek/budzet-miasta/2019/ (data dostępu: 20.11.2019).

https://bip.poznan.pl/bip/budzet-miasta-poznania,lib,1003/ (data dostępu: 20.11.2019).

https://bip.um.bydgoszcz.pl/finanse/budzet_miasta_bydgoszcz/ (data dostępu: 20.11.2019).

https://bip.uml.lodz.pl/wladze/rada-miejska-w-lodzi/projekt-budzetu-miasta-lodzi/ (data dostępu: 20.11.2019).

https://bip.um.wroc.pl/artykuly/322/budzet-miasta (data dostępu: 20.11.2019).

https://bip.zielonagora.pl/202/Budzet_miasta/ (data dostępu: 20.11.2019).

https://www.bip.bialystok.pl/finanse/budzet_miasta/ (data dostępu: 20.11.2019).

http://www.bip.kielce.eu/podglad/-/asset_publisher/BAkP/content/23-budzet-miasta-kielce/

(data dostępu: 20.11.2019).

https://www.bip.krakow.pl/?id=42 (data dostępu: 20.11.2019).

https://www.bip.um.opole.pl/?id=42684 (data dostępu: 20.11.2019).

Izdebski, H., (2011). Samorząd terytorialny. Podstawy ustroju i działalności. Warszawa: LexisNexis Polska.

Jankowska, K., (2018). Bloger jako doradca zakupowy. Budowanie zaufania i relacji z odbiorcą na przykładzie blogów www.macademiangirl.com i www.ekskluzywnymenel.com. Zarzadzanie Mediami, $n r$ 3, s. 235-249.

Kodeks Etyki Reklamy. Pobrano z: www.radareklamy.pl (data dostępu: 13.11. 2019).

Konstytucja RP (Dz.U. 1997, nr 78, poz. 483).

Kowalik, K., (2018). Media online samorządów lokalnych — nowa struktura w systemie medialnym. Próba ujęcia in statu nascendi. Zeszyty Prasoznawcze $n r$ 3, s. 429-448.

Krawczyk, D., (2017). Postrzeganie prasy samorządowej przez środowisko dziennikarskie. Kontrowersje wokół wydawania periodyków przez jednostki samorządu terytorialnego. Państwo i Spoleczeństwo, $n r$ 3, s. 55-68.

Kuzior, A., (2014). Dekada edukacji dla zrównoważonego rozwoju. Zeszyty Naukowe. Organizacja i Zarzadzanie Politechniki Ślaskiej, z. 72, s. 87-100.

Piechota, G., (2016). Analiza roli gazet samorządowych w okresie sprawowania władzy i podczas kampanii wyborczej. Zarzadzanie Publiczne, $n r 2$ (36), s. 70-84. 
Pieriegud, J., (2016). Cyfryzacja gospodarki i społeczeństwa - wymiar globalny, europejski i krajowy. W: J. Gajewski, W. Paprocki, J. Pieriegud (red.), Cyfryzacja gospodarki i społeczeństwa - szanse i wyzwania dla sektorów infrastrukturalnych (s. 11-39). Gdańsk: Instytut Badań nad Gospodarką Rynkową — Gdańska Akademia Bankowa.

Płuchowska, D., (2017). Reklama — standaryzacja reklamy interkulturowej. W: M. Wszołek (red.), Manual - Reklama. Podręcznik z zakresu projektowania komunikacji (s. 429467). Wrocław: Wydawnictwo Libron.

Rachwał, H., (2019). Reklama zewnętrzna jako element wzmacniający kampanie rekrutacyjne szkół wyższych. Marketing Instytucji Naukowych i Badawczych nr 2, s. 27-51.

Słowik, D., (2012). Granice dopuszczalności wykorzystania seksu w reklamie w uchwałach Komisji Etyki Reklamy. Państwo i Społeczeństwo, nr 3, s. 79—95.

Stownik języka polskiego PWN. Pobrano z: sjp.pwn.pl (data dostępu: 29.09.2019).

Szromnik, A., (2015). City placement - nowy element $w$ strategii zintegrowanej komunikacji marketingowej miast. W: A. Szromnik (red.), Marketing terytorialny. Nowe obszary i narzędzia (s. 100-155). Kraków-Legionowo: Wydawnictwo edu-Libri.

Tkocz, A., (2016). Rola marketingu społecznego w kształtowaniu zmian społecznych. Prace Naukowe Uniwersytetu Ekonomicznego we Wrocławiu, nr 458, s. 23-32.

Ustawa z dnia 29 grudnia 1992 r. o radiofonii i telewizji (Dz.U. 1993, nr 7, poz. 34).

Ustawa z dnia 5 czerwca 1998 roku o samorządzie powiatowym (Dz.U. 1998, nr 91, poz. 578).

Ustawa z dnia 8 marca 1990 roku o samorządzie gminnym (Dz.U. 1990, nr 16, poz. 95).

Ustawa z dnia 9 marca 2017 roku o związku metropolitalnym w województwie śląskim (Dz.U. z 2017, poz. 730).

Wszołek, M., (2016). Reklama. Perspektywa empiryczna. Wrocław: Wydawnictwo Libron.

Dariusz Krawczyk, dr, członek Polskiego Towarzystwa Komunikacji Społecznej oraz Komisji Nauk Organizacji i Zarządzania oddziału Polskiej Akademii Nauk w Katowicach, wykładowca akademicki (Uniwersytet Śląski w Katowicach), biegły sądowy z zakresu komunikacji społecznej i zarządzania ustanowiony przy Sądzie Okręgowym w Gliwicach, naczelnik Wydziału Kontaktów Społecznych Urzędu Miejskiego w Zabrzu. 